\title{
Characteristic and Self-Life Test of Food Bar with Combination of White Millet, Snakehead Fish and Soy Flour
}

\author{
Lukita Purnamayati $^{1 *}$, Raden Baskara Katri Anandito ${ }^{2}$, Siswanti ${ }^{2}$ and Edhi Nurhartadi ${ }^{2}$ \\ ${ }^{1}$ Departement of Fisheries, Faculty of Fisheries and Marine Science, Universitas Diponegoro, \\ Semarang, Indonesia; ${ }^{2}$ Department of Food Science and Technology, Faculty of Agriculture, \\ Universitas Sebelas Maret, Surakarta, Indonesia \\ *Corresponding author: lukita_anandito@yahoo.com
}

\begin{abstract}
Emerging food is needed when a disaster occurs. Emergency conditions encourage the provision of ready-to-eat-food with sensory properties which can be accepted by people, has sufficient nutrient content to meet the body's calorie needs and resistant during storage. This study was aimed to obtain the best formulas of the food bar based on the parameters observed, such as sensory, chemical, total calorie, $a_{w}$ and shelf life estimation with the Accelerated Shelf Life Test. The food bar made from white millet flour and fish koya made from snakehead fish and soy flour. Intermediate moisture food (IMF) applied in this study with the initial formulation specified by using the mass equilibrium. The effectiveness test used to determine the best formula based on all observed parameters. The results showed that the best food bar formula was F2 with moisture content $(20.99 \pm 0.21 \%)$; ash $(3.45 \pm 0.35 \%)$; fat $(18.10 \pm 0.13 \%)$; protein $(12.24 \pm 0.28 \%)$; and carbohydrates $(45.22 \pm 0.32 \%)$, aw $(0.76 \pm 0.01)$; and total calories (per $50 \mathrm{~g}$ ) $232.04 \pm 1.96 \mathrm{kcal}$. The shelf life was 19 days. Based on the results, the total calories produced from the best formula did not meet the standards.
\end{abstract}

Keywords: emerging food, fish koya, shelf-life

Cite this as: Purnamayati, L., Anandito, R. B. K., Siswanti, \& Nurhartadi, E. (2019). Characteristic and SelfLife Test of Food Bar with Combination of White Millet, Snakehead Fish and Soy Flour. Caraka Tani: Journal of Sustainable Agriculture, 34(1), 101-114. doi: http://dx.doi.org/10.20961/carakatani.v34i1.27592

\section{INTRODUCTION}

Snakehead fish (Channa striata) can be found in Indonesia, especially in Java, Kalimantan and Sulawesi (Asfar et al., 2014; Ndobe et al., 2017). Snakehead fish has a high protein content around 66\% (dry) (Prastari et al., 2017). Snakehead fish contains essential amino acids and high essential fatty acids, especially arachidonic acid and omega-3 fatty acids, called $\mathrm{C}_{22: 6}$ which beneficial for health (Haniffa et al., 2014; Rahman et al., 2018). During this time, Snakehead fish are widely used as raw materials for pharmaceutical industries (Ndobe et al., 2017). Besides, fish protein concentrate as a source of Snakehead fish albumin can be used as a functional food (Asfar et al., 2014; Romadhoni et al., 2016). Based on these advantages, Snakehead fish has the potential to be used as a source of protein in processed foods such as food bars.

The food bar is fast food in the form of sticks, rich in nutrition and filling, suitable for emerging food. This food is essential, especially during disasters and minimum water, considering that Indonesia is a disaster-prone country such as landslides, volcanic eruptions and floods. As an emerging food, the food bar is expected to meet the daily calorie needs of humans, which is around 233-250 kcal $50 \mathrm{~g}^{-1}$ of material (Kusumastuty et al., 2015), with a moisture content of 15-40\%,35$45 \%$ fat, $40-50 \%$ carbohydrates and $10-15 \%$ protein (Zoumas et al., 2002).

\footnotetext{
* Received for publication February 4, 2019

Accepted after corrections March 31, 2019
} 
Food bar can be made from local Indonesian ingredients. Several studies have been conducted to produce food bar formula such as banana based (Rahman et al., 2011), rice bran, corn (Kusumastuty et al., 2015) and taro flour (Jariyah et al., 2017). Research on food bars then developed using high-protein ingredients such as soybean flour (Ekafitri and Isworo, 2014), green bean flour (Ladamay and Yuwono, 2014) and tempeh flour (Aini et al., 2018).

Other local ingredients such as cereals are also potentially used as ingredients in making food bars, one of them is millet seeds (Panicum miliceum L.). Nowadays, millet seeds mostly used as bird feed. Millet seeds have the potential to be used as food because the nutritional content is close to rice and wheat (Marta et al., 2016). Several studies used millet as an ingredient in the formulation of mother's milk supplementary food products (Husna et al., 2012; Ardhianditto et al., 2013; Anandito et al., 2016a) and flake making (Malinda et al., 2013). Millet utilization in food bar is still rare.

Due to the high carbohydrate content in millet, encourages the addition of other high-protein ingredients in the manufacture of food bars. Anandito et al. (2016) used white millet flour as an ingredient in making food bars, combined with red bean flour as a source of protein. Need further research on the use of millet flour and animal protein in the manufacture of food bars, so this research was conducted.

The snakehead fish addition in the form of koya expected to produce rich nutrients and functional benefits, also facilitate the food bar formulation. Fish koya is a powder food supplement by sprinkled (Regina et al., 2012). Food bars must be acceptable to the community based on their sensory. One of the sensory properties of the food bar is the odor. Fishy odor in fish will affect the sensory characteristics of the food bar. Therefore, the Snakehead fish koya is added by soy flour (Glycine max) to cover the fishy smell. Also, adding soy flour also contributes to increasing the protein content of food bars.

A food bar as emerging food is expected to survive during storage. Food bar might decrease in its quality both physically and chemically. During storage, the food bar might change in sensory quality attributes such as discoloration, texture, aroma and taste and decreasing its nutritional value. Therefore, determining the shelf life of a food bar is very important. The purpose of this study was to determine the chemical characteristics of a food bar combination of white millet flour, snakehead fish and soy flour and to determine the shelf life estimation of food bar formulation.

\section{MATERIALS AND METHOD}

\section{Material}

The material used was white millet (Panicum miliceum L.) obtained from Depok Market, Surakarta, Central Java, Snakehead fish (Channa striata) obtained from Cengklik Reservoir, Boyolali, Central Java and local soybeans obtained from Grobogan, Central Java. The ingredients for making koya such as red onion, garlic, candlenut, coriander, ginger, galangal, lemongrass leaves, bay leaves, kaffir lime leaves, brown sugar, salt and coconut milk obtained from Depok Market, Surakarta, Central Java.

\section{Equipment}

The equipment that used for the manufacture of food bars were disk mill (SMJIM Models: FFC15, Indonesia), drum dryers (Armfiel, UK), oven (Memmert, Germany) and kitchen appliances. Equipment for shelf life testing used an incubator (Memmert, Germany). Beside, glassware was also used for analyzing food bars.

\section{Instant white millet flour production}

The flour made based on Anandito et al. (2015) by sifting 80 mesh size on white millet flour after removing the husk. White millet flour then heated by adding water with a ratio of white millet flour and water 1: 2 (white millet flour: water $=1: 2$ (b:v)) until boiling. Heating process finished if white millet pulp formed. Instant white millet flour produced by grinding white millet pulp on a drum dryer at $115^{\circ} \mathrm{C}$ with a rotational speed of 2 rpm.

\section{Minced snakehead fish}

Snakehead fish was cleaned by removing the head, tail, scales and viscera. Snakehead fish was then washed and filleted. Furthermore, the fish meat was steamed at $\pm 100^{\circ} \mathrm{C}$ for 10 minutes. After steaming process, the meat was minced.

\section{Making soybean flour}

Soybeans were roasted for approximately 30 minutes until the color becomes browned. Roasted soybeans then crushed and sifted to a size of 60 mesh. 


\section{Making snakehead-soybean koya}

Koya was made based on Regina et al. (2012). Koya spices consisted of mashed shallot, garlic, candlenut and coriander. The spices mixed with thick coconut milk, ginger, galangal, crushed lemongrass leaves, bay leaves, kaffir lime leaves, brown sugar and salt and then boiled. After the coconut milk and spices boiled, the ground snakehead was inserted and stirred for \pm 1 hour until browned. After that, the soy flour was added and mixed until it was even to dry. The ratio between ground Snakehead fish and soy flour 3: 2 . The mixture was then mashed.

\section{Determination of the initial formula}

Determination of the initial formula of the product based on Anandito et al. (2016) using the principle of mass equilibrium. Calculating the amount of input material must be equal to the amount of output produced (incoming material = result material). The initial formula for the product was determined based on the nutritional requirements of emerging food, which contains minimum calories of $233 \mathrm{kcal} \mathrm{bar}^{-1}$. This value based on the assumption that one bar was equal to $50 \mathrm{~g}$. The formula of the food bar presented in Table 1.

Table 1. Food bar formulation

\begin{tabular}{lccc}
\hline \multirow{2}{*}{\multicolumn{1}{c}{ Ingredient }} & \multicolumn{3}{c}{ Results $\left(\% \mathrm{w} \mathrm{w}^{-1}\right)$} \\
\cline { 2 - 4 } & $\mathrm{F} 1$ & $\mathrm{~F} 2$ & $\mathrm{~F} 3$ \\
\hline White millet flour & 22 & 26 & 30 \\
Snakehead-soybean Koya & 30 & 26 & 22 \\
Sugar & 16 & 16 & 16 \\
Margarine & 14 & 14 & 14 \\
Full cream milk & 18 & 18 & 18 \\
\hline
\end{tabular}

Note: $\mathrm{F} 1=$ Formula $1 ; \mathrm{F} 2=$ Formula $2 ; \mathrm{F} 3=$ Formula 3
The ingredients used in the formulation were millet flour as a source of carbohydrates, snakehead-soybean koya as a source of protein, powdered full cream milk as a source of protein, fat and enhance the flavor and margarine as a source fat. Sugar added to sweeten the product and as carbohydrate sources. Nutritional content of macronutrient constituent of food bars used to calculate the total calorie. The ingredients of the food bar and its macronutrient content showed in Table 2.

Table 2. Macronutrient content of food bar ingredients

\begin{tabular}{|c|c|c|c|}
\hline \multirow{2}{*}{ Ingredient } & \multicolumn{3}{|c|}{$\begin{array}{c}\text { Macronutrient } \\
\left(\mathrm{g} 100 \mathrm{~g}^{-1} \text { materials }\right)\end{array}$} \\
\hline & Carbohydrate & Fat & Protein \\
\hline $\begin{array}{l}\text { Millet } \\
\text { instant flour }\end{array}$ & 83.27 & 2.26 & 8.23 \\
\hline $\begin{array}{l}\text { Snakehead- } \\
\text { soybean } \\
\text { Koya }^{\mathrm{b}}\end{array}$ & 32.57 & 15.53 & 36.61 \\
\hline Margarine & 0.40 & 81.00 & 0.60 \\
\hline $\begin{array}{l}\text { Refined } \\
\text { sugar }\end{array}$ & 94.00 & 0.00 & 0.00 \\
\hline $\begin{array}{l}\text { Full cream } \\
\text { milk }\end{array}$ & 40.00 & 26.00 & 27.00 \\
\hline Note: ${ }^{\mathrm{a}}=$ proxin & composit & $\begin{array}{l}\text { ndito } \\
\text { utro }(2 \\
\text { ssed or }\end{array}$ & $\begin{array}{l}\text { al. }(2015) \\
6) ; \\
\text { KBM }\end{array}$ \\
\hline
\end{tabular}

Each macronutrient had a calorific value (carbohydrate $4 \mathrm{kcal} \mathrm{g}^{-1}, 4 \mathrm{kcal} \mathrm{g}^{-1}$ protein and 9 $\mathrm{kcal} \mathrm{g}^{-1}$ fats), so the total calorie value of the food bar is known by multiplying the calories of each macronutrient with the amount of macronutrient input from the food bar. The total calorie value of the food bar based on the formula showed in Table 3.

Table 3. Food bar total calorie

\begin{tabular}{lcccccc}
\hline \multirow{3}{*}{ Macronutrient } & \multicolumn{9}{c}{ Food bar formulation } \\
\cline { 2 - 7 } & \multicolumn{2}{c}{ F1 } & \multicolumn{2}{c}{ F2 } & \multicolumn{2}{c}{ F3 } \\
\cline { 2 - 7 } & $\begin{array}{c}\text { Calorie } \\
(\mathrm{kcal})\end{array}$ & $\begin{array}{c}\text { \% of total } \\
\text { calorie }\end{array}$ & $\begin{array}{c}\text { Calorie } \\
(\mathrm{kcal})\end{array}$ & $\begin{array}{c}\text { \% of total } \\
\text { calorie }\end{array}$ & $\begin{array}{c}\text { Calorie } \\
(\mathrm{kcal})\end{array}$ & $\begin{array}{c}\text { \% of total } \\
\text { calorie }\end{array}$ \\
\hline Carbohydrate & 97.03 & 41.29 & 101.08 & 43.11 & 105.14 & 44.95 \\
Protein & 35.50 & 15.10 & 33.23 & 14.17 & 30.96 & 13.24 \\
Fat & 102.58 & 43.63 & 100.19 & 42.73 & 97.81 & 41.81 \\
\hline Total calorie & \multicolumn{2}{c}{$235.11 \mathrm{kcal}$} & \multicolumn{2}{c}{$234.51 \mathrm{kcal}$} & $233.91 \mathrm{kcal}$ \\
\hline
\end{tabular}

Note: $\mathrm{F} 1=$ Formula $1 ; \mathrm{F} 2=$ Formula $2 ; \mathrm{F} 3=$ Formula 3 


\section{Making a food bar}

Food bar made based on Anandito et al. (2016) with modifications to the temperature and baking time. The ingredients were used to make a food bar were instant white millet flour, fish koya (Snakehead fish and soy flour), margarine, refined sugar, full cream milk powder and water. The ingredients was mixed then was stirred and added water until blended. Next, the blended mixture was formed on the pan. After that, the dough was baked in an oven at $140{ }^{\circ} \mathrm{C}$ for 30 minutes. Removed the food bar from the oven and let it set. The food bar then packed using aluminum foil.

\section{Analysis of the food bar}

The food bar then subjected to sensory analysis (test of preference), chemical composition, water activity $\left(\mathrm{a}_{\mathrm{w}}\right)$ and caloric value. Sensory analysis used as preference test based on Setyaningsih et al. (2010) by using 60 untrained panelists, with parameters of color, aroma, taste, texture and overall, with scales of 1-5 in the order: (1) like, (2) rather like, (3) neutral, (4) rather dislike, (5) dislike.

Chemical analysis including moisture content using the thermogravimetric method, ash content using ignition method, fat content using the Soxhlet method, protein content using the Kjeldahl method and carbohydrate content using a method called by difference (AOAC, 1995). Water activity measured using $\mathrm{a}_{\mathrm{w}}$ meter (Apriyantono et al., 1989) and calorific value using Bomb Calorimeter method (Mulyaningsih and Rosida, 2002).

In order to determine the best food bar formula-tested by, the effectiveness test was conducted (de Garmo, 1984). The test was carried out by giving the weight or score on each parameter observed according to its importance on a product, with a range of values $0-1$, referred to as variable weight (VW). Normal weight (NW) is the value of VW divided by total VW. The effectiveness value (NE) calculated by dividing the difference in parameter values and the lowest parameter value with the difference between the highest and lowest parameter values. While the yield value (YV) obtained by multiplying NE and NW.
Effectiveness value $(\mathrm{NE})=$

(Parameters value-lowest values)

(Highest values-lowest values)

Yield value $(\mathrm{YV})=\mathrm{NE} \mathrm{x}$ normal weight $(\mathrm{NW})$

\section{Food bars self-life}

Estimating the shelf life of a food bar was tested by Accelerated Shelf Life Test Arrhenius (ASLT) method. Samples then stored in an incubator at 3 different temperatures, $40^{\circ} \mathrm{C}, 45^{\circ} \mathrm{C}$ and $50^{\circ} \mathrm{C}$ for 28 days. Sensory tests including color, taste, texture, ease of swallowing and overall were carried out on days $0,7,14,21$ and 28 . The sensory test results then processed into an Arrhenius plot so the reaction rate constants can be known as a function of temperature. Shelf life was calculated based on the reaction rate order of the reaction, with zero order $\mathrm{t}=\left(\mathrm{Q}_{0}-\mathrm{Q}\right) / \mathrm{k}$ and first-order $\mathrm{t}=\left(\ln \left(\mathrm{Q}_{0} / \mathrm{Q}\right)\right) / \mathrm{k}$

Description:

$\mathrm{Q}_{0} \quad=$ Score of the first day to 0

$\mathrm{Q} \quad=$ Critical score

$\mathrm{k} \quad=$ reaction speed constant

$\mathrm{t}=$ storage time (in days, months or years)

\section{Statistical analysis}

This study using a completely randomized design of one factor, the composition of white millet flour and a mixture of Snakehead fish and soy flour as a primary ingredient in making the food bar. The data obtained was carried out statistical analysis using one-way ANOVA (Analysis of Variance). If there was a significant difference, then proceed using DMRT (Duncan Multiple Range Test) at the significance level $\alpha=$ 0.05 .

\section{RESULTS AND DISCUSSION}

\section{Food bar characteristic}

\section{Sensory properties}

The result of sensory analysis of food bar based on white millet flour with snakeheadsoybean koya showed in Table 4. Based on the sensory analysis, the three formulas of food bar were not significantly different in color and texture parameters, while for taste parameters and overalls were significantly different. 
Table 4. Sensory properties

\begin{tabular}{cccccc}
\hline \multirow{2}{*}{ Formula } & \multicolumn{5}{c}{ Parameter } \\
\cline { 2 - 6 } & Color & Aroma & Taste & Texture & Overall \\
\hline F1 & $2.28 \pm 0.90^{\mathrm{a}}$ & $2.13 \pm 0.89^{\mathrm{a}}$ & $2.23 \pm 0.74^{\mathrm{b}}$ & $2.30 \pm 0.87^{\mathrm{a}}$ & $2.40 \pm 0.85^{\mathrm{b}}$ \\
F2 & $2.12 \pm 0.80^{\mathrm{a}}$ & $2.05 \pm 0.67^{\mathrm{a}}$ & $1.68 \pm 0.81^{\mathrm{a}}$ & $1.98 \pm 0.70^{\mathrm{a}}$ & $1.87 \pm 0.77^{\mathrm{a}}$ \\
F3 & $2.22 \pm 0.76^{\mathrm{a}}$ & $2.43 \pm 0.87^{\mathrm{b}}$ & $1.93 \pm 1.12^{\mathrm{a}}$ & $2.17 \pm 0.99^{\mathrm{a}}$ & $2.12 \pm 0.90^{\mathrm{ab}}$ \\
\hline
\end{tabular}

Note: the same letter in the same column showed no significant different $\alpha=0.05$

$\mathrm{F} 1=$ Formula 1, F2 $=$ Formula 2, dan F3 = Formula 3 ;

The sensory properties of food bars for color parameters ranged from 2.12 to 2.28 with a range of preference levels of rather like. The results of the sensory analysis showed no significant difference in the color parameters of the three formula food bars. The color of the three formulas food bar was dark brown. The dark brown color in the food bar came because the koya from Snakehead fish and soy flour which had a rather dark brown color. The colors of the three formulations food bar were not significantly different, in other words, the three formulas have almost the same color, dark brown. The result of the food bar showed in Figure 1.

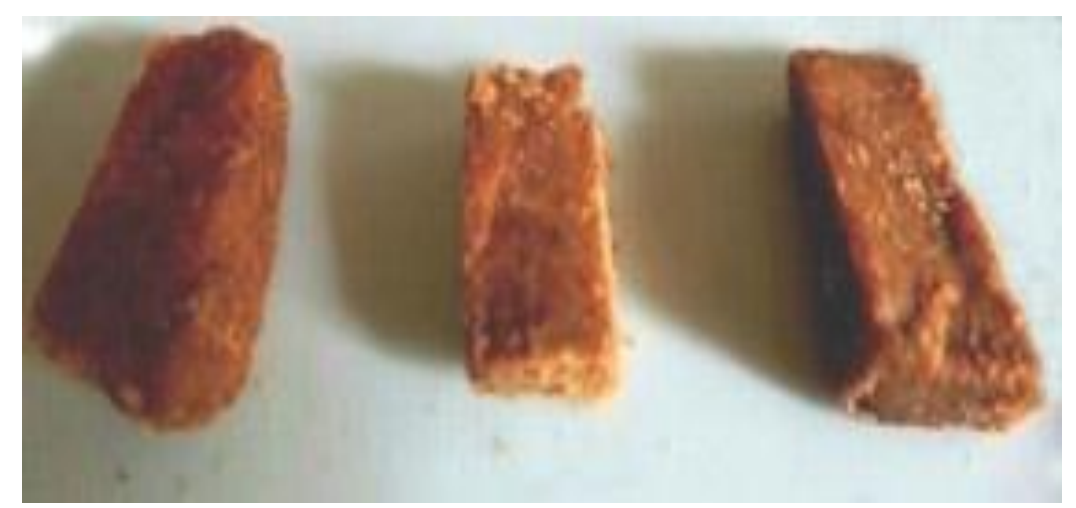

Figure 1. Food bar

The color was formed during the oven process. During the heating process, the Maillard reaction occurred between the reducing sugar and amino acids in the ingredients causing the product became brownish (Tamanna and Mahmood, 2015). The brown coloring was a melanoidin compound produced from the Maillard reaction.

The results of sensory analysis based on aroma parameters showed that the scores ranged from 2.05 to 2.43 with a preference level of rather like. The results of the sensory analysis showed that there was a significant difference in the aroma parameters, especially in the F3 formula, whereas for F1 and F2 formulas were not significantly different. It happened because of the addition of white millet flour and koya from Snakehead fish and soy flour for F1 and F2 formulations. So the formulas produced almost the same aroma. The aroma produced in the food bar was obtained from a mixture of margarine, full cream milk and koya from Snakehead fish and soy flour. The strong aroma of this food bar was the aroma of soybeans. Pertiwi et al. (2013) stated that the typical aroma of soybeans was unpleasant which could be reduced during the processing. Adiandri et al. (2012) stated that soybean aroma could be reduced by boiling. In this study, soybean aroma could be reduced because it was combined with other ingredients in the making of koya, so the more addition of snakehead-soybean koya in F1 and F2 formula were preferred by panelists.

Based on Table 4, the taste parameter had a score ranging from $1.68-2.23$ with a range of preference level of like. The results of the sensory analysis showed that there were significant differences based on taste parameters. F1 formula was significantly different from F2 and F3 formulas. The assessment obtained for F1 was 2.23; for F2 was 1.68 and for F3 was 1.93. The F1 formula showed that the food bar with the highest part of snakehead-soybean koya and the lowest part of instant millet had a low value that means the panellist like the product. The taste score was low in F1 formula because it had a strong fishy smell and slightly bitter aftertaste. This result was following the research by Anandito et al. (2015), 
food bars of white millet flour, green bean flour and soy flour have a bitter aftertaste. Bitter taste arose due to the content of tannins presented in white millet and soybeans. Kutsukutsa et al. (2014) stated that tannin could cause a bitter taste. Millet had a tannin content which was an antinutrient agent (Rani et al., 2018). The tannin content in millet flour had decreased during high temperature processing. Micahel and Admassu (2017) stated that tannin decreased during the extrusion process at $130^{\circ} \mathrm{C}$. The tannin content in

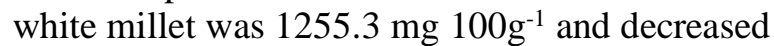
by $78.19 \%$ during the extrusion process. Soybeans also had tannin content. Wardani and Wardani (2014) stated that soybeans contained tannins which caused a bitter taste. According to Jiao et al. (2012) the tannin content in soybeans ranged from 1.76-3.6\%. Therefore, the lower addition of instant millet flour and the higher snakeheadsoybean koya provided an increasingly bitter taste.

Based on the sensory analysis, the three formulas tended to be favored by panelists. The results of this study showed different things from previous studies using white millet flour. Anandito et al, (2015) made food bars by using white millet flour by adding pulses of flour and glycerol to produce a sensory parameter for taste with a rather like to neutral level of preference. Anandito et al. (2016) added parboiled kidney beans to food bars to produce flavor with a range of acceptance rather dislike to rather like. The addition of snakehead-soybean koya could improve the sensory properties of the food bar in taste parameter.

Texture parameters showed scores ranging from $1.98-2.30$ with a range of like to rather like. The result for F1 was 2.30; for F2 was 1.98 and for F3 was 2.17. The results showed no significant difference based on texture parameters. The three formulas of food bar had not too hard texture, nor too dry and dense. The texture of the food bar did not cause thirst and easily swallowed when consumed.

Based on the overall parameters, F1 formulation was significantly different from F2 formulation, while the F1 with F3 and F2 with F3 formulation was not significantly different. The assessment obtained for $\mathrm{F} 1$ was 2.40; F2 was 1.87 and F3 was 2.12. Overall, the food bar formulation preferred by the panelist was F2 formula.

\section{The chemical composition of food bar}

The chemical composition analysis was carried out to determine the chemical content presented in the food. In this study, the chemical composition analysis of the food bar was carried out for all formulas so it could be known which formula had the chemical composition following the standards. The chemical composition of the three formulas showed in Table 5 .

Table 5. The chemical composition of food bar

\begin{tabular}{clcccc}
\hline No. & Chemical composition & $\mathrm{F} 1$ & $\mathrm{~F} 2$ & $\mathrm{~F} 3$ & $\begin{array}{c}\text { Standard } \\
\text { (adapted from } \\
\text { Zoumas et al., } \\
2002)\end{array}$ \\
\hline 1. & Moisture content $(\% \mathrm{wb})$ & $21.14 \pm 0.68^{\mathrm{a}}$ & $20.99 \pm 0.21^{\mathrm{a}}$ & $20.78 \pm 0.26^{\mathrm{a}}$ & $10-40$ \\
2. & Ash $(\% \mathrm{wb})$ & $3.85 \pm 0.06^{\mathrm{a}}$ & $3.45 \pm 0.35^{\mathrm{a}}$ & $3.48 \pm 0.05^{\mathrm{a}}$ & - \\
3. & Fat $(\% \mathrm{wb})$ & $17.91 \pm 0.66^{\mathrm{a}}$ & $18.10 \pm 0.13^{\mathrm{a}}$ & $17.71 \pm 0.32^{\mathrm{a}}$ & - \\
& $(\%$ total calories) & 41.38 & 41.47 & 40.72 & $35-45$ \\
4. & Protein $(\% \mathrm{wb})$ & $13.26 \pm 0.28^{\mathrm{c}}$ & $12.24 \pm 0.28^{\mathrm{b}}$ & $11.27 \pm 0.24^{\mathrm{a}}$ & - \\
& (\% total calories) & 13.61 & 12.46 & 11.51 & $10-15$ \\
5. & Carbohydrate $(\% \mathrm{wb})$ & $43.84 \pm 0.87^{\mathrm{a}}$ & $45.22 \pm 0.32^{\mathrm{b}}$ & $46.76 \pm 0.29^{\mathrm{c}}$ & - \\
& (\% total calories) & 45.01 & 46.06 & 47.77 & $40-50$ \\
6. & Calorie (kcal $\left.50 \mathrm{~g}^{-1}\right)$ & $223.61 \pm 2.54^{\mathrm{b}}$ & $232.04 \pm 1.96^{\mathrm{c}}$ & $209.99 \pm 2.27^{\mathrm{a}}$ & $>233$ \\
7. & Water activity & $0.78 \pm 0.02^{\mathrm{a}}$ & $0.76 \pm 0.01^{\mathrm{a}}$ & $0.75 \pm 0.00^{\mathrm{a}}$ & $0.60-0.85$ \\
\hline
\end{tabular}

Note: the same letter at the same row showed no significant different $\alpha=0.05$

F1 = Formula 1, F2 = Formula 2, F3 = Formula 3

Table 5 showed the moisture content of the three formulas, F1 21.14\%; F2 20.99\% and F3 $20.78 \%$. The moisture content of the three formulas was not significantly different and following the requirements, between $15-40 \%$ (Zoumas et al., 2002). The more koya from 
Snakehead fish and soy flour, the higher the moisture content of the food bar. The raw material for making koya was Snakehead fish and soy flour and each had high protein content. The protein had ionic strength which able to bind water (Trianto et al., 2013), the more koya to produce food bars would increase the moisture content.

The ash content of the three formula was $3.85 \% \quad \mathrm{~F} 1 ; 3.45 \% \quad \mathrm{~F} 2$ and $3.482 \% \quad \mathrm{~F} 3$ and significantly different in the three formulas. The ash content produced from this study was higher than Anandito et al. (2016) which produced a food bar with $1.45 \%$ ash content. This due to the high ash content of snakehead and soybean. Prastari et al. (2017) stated that the ash content of Snakehead fish was $15.4 \%$ while soybean ash content ranged from 5-6\% (Astawan et al., 2013).

The three formulas showed not significantly different on fat content that was. F1 fat content was $17.91 \%$; F2 $18.10 \%$ and F3 $17.71 \%$. The fat content of food bar based on white millet flour with the addition of snakehead-soybean koya per bar $(50 \mathrm{~g})$ for $\mathrm{F} 18.96 \mathrm{~g}$ or equivalent to $41.38 \%$ of total calories, for F2 $9.05 \mathrm{~g}$ or equivalent $41.47 \%$ of total calories and for F3 $8.86 \mathrm{~g}$ or equivalent to $40.72 \%$ of total calories and in accordance with emerging food standards, which had $35-45 \%$ of total calories (Zoumas et al., 2002).

The protein content of the three food bar formulas showed significantly different results. F1 protein content was $13.26 \%$; F2 12.24\%; and F3 $11.27 \%$. Table 5 showed that the protein content of food bar based on white millet flour with the addition of snakehead-soybean koya per bar $(50 \mathrm{~g})$ for $\mathrm{F} 1$ was $6.63 \mathrm{~g}$ or equivalent to $13.61 \%$ of total calories. For F2 $6.12 \mathrm{~g}$ or equivalent to $12.43 \%$ of total calories and for F3 $5.63 \mathrm{~g}$ or equivalent to $11.51 \%$ of total calories and following emerging food standards which had $10-15 \%$ of total calories (Zoumas et al., 2002 )

The addition of Snakehead-soybean koya in the food bar formulations was increased the protein content. Due to the high protein content in snakehead fish and soybean. The protein content in Snakehead fish was $66.67 \%$ in dry weight (Prastari et al., 2017) while the protein content in soybeans ranged from $37-41 \%$ (Astawan et al., 2013). Therefore, the more koya, the higher the protein content of the food bar.

The three food bars formula had significantly different carbohydrate levels. F1 carbohydrate content was 43.84\%; F2 45.22\% and F3 46.76\%.
Carbohydrate content per bar (50 g) based on white millet flour with the addition of Snakeheadsoybean koya for F1 amounted to be $21.92 \mathrm{~g}$ or equivalent to $45.01 \%$ of total calories, for F2 $22.61 \mathrm{~g}$ or equivalent $46.06 \%$ of total calories and F3 $23.38 \mathrm{~g}$ or equivalent to $47.77 \%$ of total calories. Zoumas et al. (2002) stated that emerging food standards had carbohydrates content about $40-50 \%$ of total calories. The results of the carbohydrate content of the food bar in this study were following the standards.

\section{Total calories}

The standard for total calories in emerging

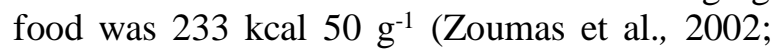
Kusumastuty et al., 2015). The total calories of food bar that produced from this study per bar (50 g): F1 $223.61 \mathrm{kcal}$; F2 $232.04 \mathrm{kcal}$ and F3 209.99 $\mathrm{kcal}$. Based on the three formulas, the highest calories were obtained in the F2 formulation and the lowest in the F3 formulation. All three formulas had total calories below emerging food standards. However, the total calorie that was close to the emerging food standard was F2 of

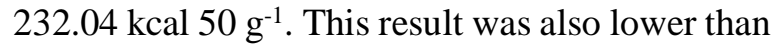
the predicted result. Based on predictions, the total calories for the F2 formula were $234.51 \mathrm{kcal}$ $50 \mathrm{~g}^{-1}$. The result was lower than this prediction due to the fiber content in millet and soybeans. Food fiber was a part of plants that cannot be digested in the small intestine but fermented in the large intestine, so it did not produce energy or calories (Lattimer and Haub, 2010; Dhingra et al., 2012). White Millet contained fiber as much as $2.20 \%$ (Singh, 2016), while soybeans were known as a source of food fiber with a total fiber of 5.56$8.58 \%$ (Ratnaningsih et al., 2017). Calorie needs per day, which is equal to $2100 \mathrm{kcal}$, could be met by consuming as many as 3-4 bars per consumption (one meal) and done three times a day.

\section{Water activity $\left(\mathbf{a}_{\mathbf{w}}\right)$}

Emerging food must have water activity between $0.60-0.80$ (Zoumas et al., 2002) associated with microbial growth. The three formulas had $\mathrm{a}_{\mathrm{w}}$ : F1 0.78; F2 0.76 and F3 0.75. The results of the water activity $\left(a_{w}\right)$ showed no significantly different and following the standard. The value of $a_{w}$ was related to the shelf life of the food bar in terms of microbiology. Microbes could grow in food, especially yeast $\left(\mathrm{a}_{\mathrm{w}} 0.88\right)$ and bacteria $\left(a_{w}>0.90\right)$ (Yusuf et al., 2016). All of them had $\mathrm{a}_{\mathrm{w}}$ ranging from $0.7-0.8$. Although it had 
fulfilled the standard for food bar, it should be kept in dry place and not damp to prevent the growth of fungus.

Determining for the best formula for food bar

The best formula for the food bar was determined by the effectiveness index test (de Garmo, 1984) showed in Table 6. The principle of effectiveness index testing was to give weights or scores on the quality characteristics of each formula (Sappu et al., 2014). Determination of the best formula done by considering all parameters, in this study was sensory parameters, including color, aroma, taste, texture and overall. Besides, the chemical parameters which include moisture, ash, protein, fat, carbohydrate and total calorie values and $\mathrm{a}_{\mathrm{w}}$. All parameters had the same weight as the characteristics of a food bar. Based on the calculations in Table 6 , the best food bar formula was the F2 formula with a yield value $(\mathrm{NH})$ of 0.74 .

Table 6. Food bar effectively result

\begin{tabular}{lcccccccc}
\hline \multirow{2}{*}{ Parameter } & \multirow{2}{*}{ VW } & \multirow{2}{*}{ NW } & \multicolumn{2}{c}{ F1 } & \multicolumn{2}{c}{ F2 } & \multicolumn{2}{c}{ F3 } \\
\cline { 4 - 9 } & & & NE & YV & NE & YV & NE & YV \\
\hline Color & 1 & 0.08 & 0.00 & 0.00 & 1.00 & 0.08 & 0.37 & 0.03 \\
Aroma & 1 & 0.08 & 0.79 & 0.07 & 1.00 & 0.08 & 0.00 & 0.00 \\
Taste & 1 & 0.08 & 0.00 & 0.00 & 1.00 & 0.08 & 0.55 & 0.05 \\
Texture & 1 & 0.08 & 0.00 & 0.00 & 1.00 & 0.08 & 0.41 & 0.03 \\
Overall & 1 & 0.08 & 0.00 & 0.00 & 1.00 & 0.08 & 0.53 & 0.04 \\
Water & 1 & 0.08 & 1.00 & 0.08 & 0.58 & 0.05 & 0.00 & 0.00 \\
Ash & 1 & 0.08 & 1.00 & 0.08 & 0.00 & 0.00 & 0.07 & 0.01 \\
Fat & 1 & 0.08 & 0.51 & 0.04 & 1.00 & 0.08 & 0.00 & 0.00 \\
Protein & 1 & 0.08 & 1.00 & 0.08 & 0.49 & 0.04 & 0.00 & 0.00 \\
Carbohydrate & 1 & 0.08 & 0.00 & 0.00 & 0.47 & 0.04 & 1.00 & 0.08 \\
Total calories & 1 & 0.08 & 0.62 & 0.05 & 1.00 & 0.08 & 0.00 & 0.00 \\
Water activity & 1 & 0.08 & 1.00 & 0.08 & 0.33 & 0.03 & 0.00 & 0.00 \\
\hline Total & 12 & & & 0.49 & & 0.74 & & 0.24 \\
\hline
\end{tabular}

Note: $\mathrm{VW}=$ variable weight, $\mathrm{NW}=$ normal weight, $\mathrm{NE}=$ effectivity value, $\mathrm{YV}=$ yield value

\section{Food bar shelf life}

Shelf life is the time of a food product that still acceptable and fulfills consumer desires for the quality of the product. Estimated shelf life aimed to control the quality and safety of food products (Martins et al., 2008). F2 was the best formula based on the effectiveness index test. F2 tested its shelf life estimation that aimed to determine the quality attribute changes during storage based on consumer acceptance (Corrigan et al., 2012). Food bars had decreased panelists acceptance of each quality attribute which includes color, taste, texture, ease of swallowing and overall over 28 days of storage at different temperatures.

Table 7 showed the decrease in panelists acceptance of all quality attributes based on the zero-order reaction and first order reaction. Based on the coefficient of determination $\left(\mathrm{R}^{2}\right)$ which close to 1 , changed in quality attributes such as color, texture and easy to swallow following the $1^{\text {st }}$ order equation while for taste and overall attributes following the zero-order reaction. The calculation of $\mathrm{k}$ values showed in Table 8 . 
Table 7. Decreasing panelists acceptance based on food bar quality

\begin{tabular}{|c|c|c|c|}
\hline \multirow{2}{*}{ Parameter } & \multirow{2}{*}{$\begin{array}{l}\text { Storage temperature } \\
\left({ }^{\circ} \mathrm{C}\right)\end{array}$} & \multicolumn{2}{|c|}{ Equation } \\
\hline & & Zero order reaction & First order reaction \\
\hline \multirow[t]{5}{*}{ Color } & 40 & $\begin{array}{c}y=-0.1302 x+6.3111 \\
R^{2}=0.9893\end{array}$ & $\begin{array}{c}y=-0.0298 x+1.8754 \\
R^{2}=0.9971\end{array}$ \\
\hline & 45 & $y=-0.1392 x+6.1926$ & $y=-0.0335 x+1.8598$ \\
\hline & & $\mathrm{R}^{2}=0.9740$ & $R^{2}=0.9960$ \\
\hline & 50 & $y=-0.1503 x+6.1407$ & $y=-0.0379 x+1.8557$ \\
\hline & & $\mathrm{R}^{2}=0.9639$ & $\mathrm{R}^{2}=0.9940$ \\
\hline \multirow[t]{6}{*}{ Taste } & 40 & $y=-0.1439 x+6.9926$ & $y=-0.0311 x+1.9934$ \\
\hline & & $\mathrm{R}^{2}=0.9924$ & $\mathrm{R}^{2}=0.9597$ \\
\hline & 45 & $y=-0.1529 x+6.8222$ & $y=-0.0344 x+1.9694$ \\
\hline & & $R^{2}=0.9982$ & $\mathrm{R}^{2}=0.9892$ \\
\hline & 50 & $y=-0.1598 x+6.7704$ & $y=-0.0372 x+1.9664$ \\
\hline & & $\mathrm{R}^{2}=0.9953$ & $\mathrm{R}^{2}=0.9927$ \\
\hline \multirow[t]{6}{*}{ Texture } & 40 & $y=-0.1413 x+6.6148$ & $y=-0.0315 x+1.9277$ \\
\hline & & $R^{2}=0.9925$ & $\mathrm{R}^{2}=0.9950$ \\
\hline & 45 & $y=-0.1503 x+6.4296$ & $y=-0.0355 x+1.8998$ \\
\hline & & $R^{2}=0.9679$ & $R^{2}=0.9803$ \\
\hline & 50 & $y=-0.1529 x+6.4296$ & $y=-0.0372 x+1.9103$ \\
\hline & & $\mathrm{R}^{2}=0.9779$ & $\mathrm{R}^{2}=0.9855$ \\
\hline \multirow[t]{6}{*}{ Ease to swallow } & 40 & $y=-0.1280 x+6.3481$ & $y=-0.0284 x+1.8729$ \\
\hline & & $R^{2}=0.9620$ & $R^{2}=0.9678$ \\
\hline & 45 & $y=-0.1328 x+6.2519$ & $y=-0.0306 x+1.8628$ \\
\hline & & $\mathrm{R}^{2}=0.9751$ & $\mathrm{R}^{2}=0.9964$ \\
\hline & 50 & $y=-0.1529 x+6.2296$ & $y=-0.0386 x+1.8761$ \\
\hline & & $\mathrm{R}^{2}=0.9742$ & $\mathrm{R}^{2}=0.9954$ \\
\hline \multirow[t]{6}{*}{ Overall } & 40 & $y=-0.1254 x+6.7407$ & $y=-0.0266 x+1.9442$ \\
\hline & & $\mathrm{R}^{2}=0.9915$ & $\mathrm{R}^{2}=0.9671$ \\
\hline & 45 & $y=-0.1460 x+6.4667$ & $y=-0.0338 x+1.9028$ \\
\hline & & $R^{2}=0.9595$ & $\mathrm{R}^{2}=0.9569$ \\
\hline & 50 & $y=-0.1545 x+6.2889$ & $y=-0.0383 x+1.8815$ \\
\hline & & $R^{2}=0.9675$ & $R^{2}=0.9935$ \\
\hline
\end{tabular}

The panelist acceptance decrease in color attributes because of the storage duration at different temperatures and discoloration from brown to blackish brown. The Maillard reaction that increased the brownish color during storage. Raisi and Aroujalian (2010) stated that the temperature affects the speed of the formation of brownish color due to the Maillard reaction. Food bars changed in taste parameter from savory sweet to slightly bitter cause a decrease in panelists acceptance of taste attributes. This change due to the formation of the Maillard reaction, especially the furan component which caused a bitter taste (Karangwa et al., 2017). Maillard reaction also caused a change in the texture of the food bar. Maillard reaction and disulfide reaction caused protein aggregation that affects the texture (Rao et al., 2013). Besides, the texture also influenced by changes in product moisture content (Banach et al., 2016). The texture of the food bar changed from not too hard to hard and dry. The change in the texture of the food bar affects the ease of the product to be swallowed. 
Table 8. k-Value and ln k equation based on quality parameters

\begin{tabular}{ccccccc}
\hline Parameter & $\begin{array}{c}\text { Storage } \\
\text { temperature } \\
\left(\mathrm{T}={ }^{\circ} \mathrm{C}\right)\end{array}$ & $\begin{array}{c}\text { Storage } \\
\text { temperature } \\
(\mathrm{T}=K)\end{array}$ & $1 \mathrm{~T}^{-1}$ & Selected order reaction & $\mathrm{k}$ & ln $\mathrm{k}$ \\
\hline Color & 40 & 313 & 0.00319 & $\mathrm{y}=-0.0298 \mathrm{x}+1.8754$ & 0.0298 & -3.5132 \\
& 45 & 318 & 0.00314 & $\mathrm{y}=-0.0335 \mathrm{x}+1.8598$ & 0.0335 & -3.3962 \\
& 50 & 323 & 0.00310 & $\mathrm{y}=-0.0379 \mathrm{x}+1.8557$ & 0.0379 & -3.2728 \\
\hline Taste & 40 & 313 & 0.00319 & $\mathrm{y}=-0.1439 \mathrm{x}+6.9926$ & 0.1439 & -1.9386 \\
& 45 & 318 & 0.00314 & $\mathrm{y}=-0.1529 \mathrm{x}+6.8222$ & 0.1529 & -1.8780 \\
& 50 & 323 & 0.00310 & $\mathrm{y}=-0.1598 \mathrm{x}+6.7704$ & 0.1598 & -1.8338 \\
\hline Texture & 40 & 313 & 0.00319 & $\mathrm{y}=-0.0315 \mathrm{x}+1.9277$ & 0.0315 & -3.4578 \\
& 45 & 318 & 0.00314 & $\mathrm{y}=-0.0355 \mathrm{x}+1.8998$ & 0.0355 & -3.3382 \\
& 50 & 323 & 0.00310 & $\mathrm{y}=-0.0372 \mathrm{x}+1.9103$ & 0.0372 & -3.2914 \\
\hline Ease to & 40 & 313 & 0.00319 & $\mathrm{y}=-0.0284 \mathrm{x}+1.8729$ & 0.0284 & -3.5614 \\
swallow & 45 & 318 & 0.00314 & $\mathrm{y}=-0.0306 \mathrm{x}+1.8628$ & 0.0306 & -3.4868 \\
& 50 & 323 & 0.00310 & $\mathrm{y}=-0.0386 \mathrm{x}+1.8761$ & 0.0386 & -3.2545 \\
\hline Overall & 40 & 313 & $0, .00319$ & $\mathrm{y}=-0.1254 \mathrm{x}+6.7407$ & 0.1254 & -2.0762 \\
& 45 & 318 & 0.00314 & $\mathrm{y}=-0.1460 \mathrm{x}+6.4667$ & 0.1460 & -1.9241 \\
& 50 & 323 & 0.00310 & $\mathrm{y}=-0.1545 \mathrm{x}+6.2889$ & 0.1545 & -1.8676 \\
\hline
\end{tabular}

Based on the calculation of the values of $\mathrm{k}$ and $\ln$, an Arrhenius plot equation value showed in Figure 2. The slope of the Arrhenius equation used to calculate the activation energy. The Arrhenius equation also used to calculate the shelf life of a food bar.

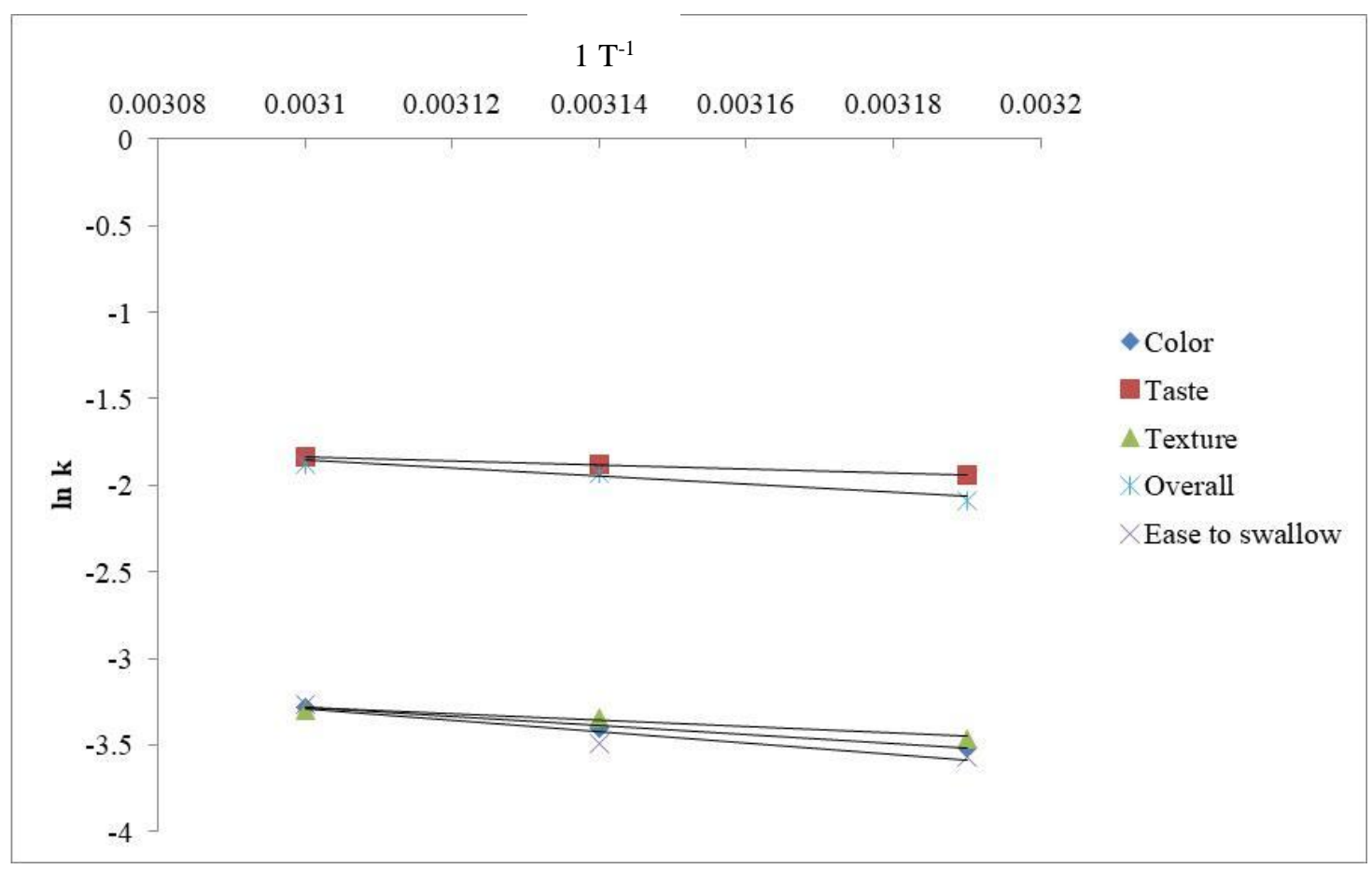

Figure 2. Plotting arrhenius in quality attribute 
Table 9. Food bars shelf life

\begin{tabular}{ccccccccc}
\hline Parameter & $\begin{array}{c}\text { Temper Temper } \\
\text { ature } \\
\left({ }^{\circ} \mathrm{C}\right)\end{array}$ & $\begin{array}{r}\text { ature } \\
(\mathrm{K})\end{array}$ & $1 \mathrm{~T}^{-1}$ & $\operatorname{ln~k}$ & $\mathrm{k}$ & $\begin{array}{c}\text { Activation } \\
\text { energy } \\
\left(\mathrm{J} \mathrm{mol} \mathrm{K}^{-1}\right)\end{array}$ & $\begin{array}{c}\text { Order } \\
\text { reaction }\end{array}$ & $\begin{array}{c}\text { Storage } \\
\text { time } \\
(\text { day })\end{array}$ \\
\hline Color & 28 & 301 & 0.0033 & -3.8694 & 0.0209 & 22094.455 & 1 & 39 \\
Taste & 28 & 301 & 0.0033 & -2.0926 & 0.1234 & 9697.450 & 0 & 19 \\
Texture & 28 & 301 & 0.0033 & -3.6971 & 0.0248 & 15556.325 & 1 & 32 \\
Easy to swallow & 28 & 301 & 0.0033 & -4.0304 & 0.0178 & 27697.260 & 1 & 44 \\
Overall & 28 & 301 & 0.0033 & -2.3761 & 0.0929 & 19517.115 & 0 & 24 \\
\hline
\end{tabular}

Based on Tables 9, two attributes met the criteria in determining shelf life including the highest $\mathrm{k}$ value and the lowest activation energy in the taste attribute, which were 0.1234 and $9697.450 \mathrm{~J} \mathrm{~mol} \mathrm{~K}^{-1}$. Activation energy was capable of measuring reaction sensitivity to temperature. Activation energy showed the amount of energy that needed to start a reaction based on the Arrhenius reaction slope (Hosseini et al., 2014). The parameter that had the lowest activation energy was the key parameters that affect product shelf life. Also, the higher reaction rate constant could accelerate the product damage reaction (Wahyuni et al., 2018). Based on taste parameter, the food bar had a shelf life at room temperature $\left(28^{\circ} \mathrm{C}\right)$ for 19 days. Different results were shown by Pulungan et al. (2016) which stated that based on its water content, plastic packaged apple pie produced a shelf life prediction at $25{ }^{\circ} \mathrm{C}$ for 164 days with water activity ranging from $0.77-0.83$. This difference in shelf life was affected by packaging materials and storage conditions (Bouzo et al., 2012; Nayik and Muzaffar, 2014).

\section{CONCLUSIONS}

The best formula for a food bar was the F2 formula with a composition of instant white millet flour 26\%; snakehead-soybean koya $26 \%$; sugar $16 \%$; margarine $14 \%$ and full cream milk $18 \%$. Based on the composition, it was produced food bar with moisture content $(20.99 \pm 0.21 \%)$; ash $(3.45 \pm 0.35 \%)$; fat $(18.10 \pm 0.13 \%)$; protein $(12.24$ $\pm 0.28 \%)$; carbohydrates $(45.22 \pm 0.32 \%) ; \mathrm{a}_{\mathrm{w}}(0.76$ \pm 0.01 ) and total calories per bar (per $50 \mathrm{~g}$ ) 232.04 $\pm 1.96 \mathrm{kcal}$. Based on taste parameters, F2 formula had a shelf life for 19 days. However, the total calories produced by the F2 food bar have not met emergency food standards.

\section{REFERENCES}

Adiandri, R. S., Darniadi, S., \& Hidayah, N.
(2012). Identifikasi Komponen Flavor pada Tepung Ubijalar, Kacang Hijau, dan Kedelai sebagai Bahan Baku Produk Snack Bars. In Prosiding Seminar Hasil Penelitian Tanaman Aneka Kacang dan Umbi (pp. 340-349).

Aini, N., Prihananto, V., Wijonarko, G., Sustriawan, B., Dinayati, M., \& Aprianti, F. (2018). Formulation and Characterization of Emergency Food Based on Instan Corn Flour Supplemented by Instan Tempeh (or Soybean) Flour. International Food Research Journal, 25(1), 287-292.

Anandito, R. B. K., Nurhartadi, E., \& Nugrahini, S. (2015). Formulasi Pangan Darurat Berbentuk Food Bars Berbasis Tepung Millet Putih (Panicum miliceum L.) dan Tepung Kacang-kacangan dengan Penambahan Gliserol sebagai Humektan. In Prosiding Seminar Agroindustri dan Lokakarya Nasional FKPT-TPI (pp. 222-230).

Anandito, R. B. K., Siswanti, \& Kusumo, D. T. (2016). Kajian Karakteristik Sensoris dan Kimia Bubur Instan Berbasis Tepung Millet Putih (Panicum miliceum L.) dan Tepung Kacang Merah (Phaseolus vulgaris L.). Jurnal Teknologi Hasil Pertanian, IX(1), 17-23.

Anandito, R. B. K., Siswanti, Nurhartadi, E., \& Hapsari, R. (2016a). Formulasi Pangan Darurat Berbentuk Food Bars Berbasis Tepung Millet Putih (Panicum milliaceum L.) dan Tepung Kacang Merah (Phaseolus vulgaris L.). Agritech, 36(1), 23-29.

AOAC. (1995). Official Methods of Analysis. Association of Official Analytical Chemists. Washington, D. C.

Apriyantono, A., Fardiaz, D., Sedarnawati, P., \& Budiyanto. (1995). Analisis Pangan. IPB Press, Bogor.

Ardhianditto, D., Anandito, B. K., Prananto, N. 
H., \& Rahmawati, D. (2013). Kajian Karakteristik Bubur Bayi Instan Berbahan Dasar Tepung Millet Kuning (Panicum sp.) dan Tepung Beras Merah (Oryza nivara) dengan Flavor Alami Pisang Ambon (Musa X Paradisiaca L) sebagai Makanan Pendamping Asi (MP-ASI). Jurnal Teknosains Pangan, 2(1), 88-96.

Asfar, M., Tawali, A. B., Abdullah, N., \& Mahendradatta, M. (2014). Extraction Of Albumin Of Snackhead Fish In Producing The Fish Protein Concentrate (FPC). International Journal of Scientific and Technology Research, 3(4), 85-88.

Asfar, M., Tawali, A. B., \& Mahendradatta, M. (2014a). Potensi Ikan Gabus (Channa Striata) sebagai Sumber Makanan Kesehatan (Review). In Prosiding Seminar Nasional Teknologi Industri II (pp. 150-154).

Astawan, M., Wresdiyati, T., Widowati, S., Bintari, S. H., \& Ichsani, N. (2013). Karakteristik Fisikokimia dan Sifat Fungsional Tempe yang Dihasilkan dari Berbagai Varietas Kedelai. Jurnal Pangan, 22(3), 241-252.

Banach, J. C., Clark, S., \& Lamsal, B. P. (2016). Instrumental and Sensory Texture Attributes of High-Protein Nutrition Bars Formulated with Extruded Milk Protein Concentrate. Journal of Food Science, 81(5), S1254-S1262. https://doi.org/10.1111/1750-3841.13270

Bouzo, C. A., Travadelo, M., \& Gariglio, N. F. (2012). Effect of Different Packaging Materials on Postharvest Quality of Fresh Fig Fruit. International Journal of Agriculture \& Biology, 14(5), 821-825.

Corrigan, V., Hedderley, D., \& Harvey, W. (2012). Modeling the Shelf Life of Fruit-Filled Snack Bars using Survival Analysis and Sensory Profilling Techniques. Journal of Sensory Studies, 27(6), 403-416. https://doi.org/10.1111/joss.12006

De Garmo, E. P., Sullivan, W. G., \& Canada, W. R. (1984). Engineering Economy. SeventhEd. New York.

Dhingra, D., Michael, M., Rajput, H., \& Patil, R. T. (2012). Dietary Fibre in Foods: A review. Journal of Food Science and Technology, 49(3), 255-266. https://doi.org/10.1007/ s13197-011-0365-5
Ekafitri, R., \& Isworo, R. (2014). Pemanfaatan Kacang-Kacangan sebagai Bahan Baku Sumber Protein untuk Pangan Darurat. Pangan, 23(2), 134-145.

Haniffa, M. A. K., Sheela, P. A. J., Kavitha, K., \& Jais, A. M. M. (2014). Salutary Value of Haruan, The Striped Snakehead Channa Striatus - A Review. Asian Pacific Journal of Tropical Biomedicine, 4(Suppl 1), S8-S15. https://doi.org/10.12980/apjtb.4.2014c1015

Hosseini, H., Ghorbani, M., Mahoonak, A., \& Maghsoudlou, Y. (2014). Monitoring Hydroperoxides Formation as a Measure of Predicting Walnut Oxidative Stability. Acta Alimentaria, 43(3), 412-418. https://doi.org/ 10.1556/aalim.43.2014.3.7

Husna, E. A., Affandi, D. R., Kawiji, \& Anandito, R. B. K. (2012). Karakterisasi Bubur Bayi Instan Berbahan Dasar Tepung Millet (Panicum sp) dan Tepung Kacang Hijau (Phaseolus radiatus) dengan Flavor Alami Pisang Ambon (Musa paradisiaca var. Sapientum 1.). Jurnal Teknosains Pangan, l(1), 68-74.

Jariyah, Karti, E., \& Pertiwi, Y. A. (2017). Evaluasi Sifat Fisikokimia Food Bar dari Tepung Komposit (Pedada, Talas dan Kedelai) sebagai Alternatif Pangan Darurat. Jurnal Rekapangan, 11(1), 70-75.

Jiao, Z., Si, X. X., Zhang, Z. M., Li, G. K., \& Cai, Z. W. (2012). Compositional Study of Different Soybean (Glycine Max L.) Varieties by $1 \mathrm{H}$ NMR Spectroscopy, Chromatographic and Spectrometric Techniques. Food Chemistry, 135(1), 285-291. https://doi.org/ 10.1016/j.foodchem.2012.04.091

Karangwa, E., Habimana, J. D. D., Jingyang, Y., Murekatete, N., Zhang, X., Masamba, K., Muhoza, B. (2017). Sensory Characteristics of Maillard Reaction Products Obtained from Sunflower Protein Hydrolysates and Different Sugar Types. International Journal of Food Engineering, 13(3). https://doi.org/10.1515/ ijfe-2016-0006

Kusumastuty, I., Fandianty Ningsih, L., \& Rio Julia, A. (2015). Formulasi Food Bar Tepung Bekatul dan Tepung Jagung sebagai Pangan Darurat. Indonesian Journal of Human Nutrition, 2(2), 68-75. 
Kutsukutsa, R. T., Gasura, E., Mabasa, S., \& Ngadze, E. (2014). Variability in Condensed Tannins and Bitterness in Spider Plant Genotypes. African Crop Science Journal, 22(4), 275-280.

Ladamay, N. A., \& Yuwono, S. S. (2014). Pemanfaatan Bahan Lokal dalam Pembuatan Foodbars (Kajian Rasio Tapioka: Tepung Kacang Hijau dan Proporsi Cmc). Jurnal Pangan Dan Agroindustri, 2(1), 67-78. https://doi.org/10.1186/1550-2783-11-19

Lattimer, J. M., \& Haub, M. D. (2010). Effects of Dietary Fiber and Its Components on Metabolic Health. Nutrients, 2(12), 12661289. https://doi.org/10.3390/nu2121266

Malinda, A. P., Katri, R. B., Rachmawanti, D., \& Riyadi, N. H. (2013). Kajian Penambahan Tepung Millet dan Tepung Ubi Jalar Ungu (lpomoea batatas L) sebagai Subtitusi Tepung Terigu pada Pembuatan Flake. Jurnal Teknosains Pangan, 2(1), 39-48.

Marta, H., Marsetio, Cahyana, Y., \& Pertiwi, A. G. (2016). Sifat Fungsional dan Amilografi Pati Millet Putih (Pennisetum glaucum) Termodifikasi secara Heat Moisture Treatment dan Annealing. Jurnal Aplikasi Teknologi Pangan, 5(3), 76-84. https://doi.org/10.17728/ jatp. 175

Martins, R. C., Lopes, V. V., Vicente, A. A., \& Teixeira, J. A. (2008). Computational ShelfLife Dating: Complex Systems Approaches to Food Quality and Safety. Food and Bioprocess Technology, 1(3), 207-222. https://doi.org/ 10.1007/s11947-008-0071-0

Micahel, H. W., \& Admassu, S. (2017). Effects of Processing on Phytonutrient and Nutritional Composition of Finger Millet (Eleusine coracana): The Neglected Crop of Africa. Ethiopian Journal of Crop Science, 5(1), 117 136.

Mulyaningsih, Y., \& Rosida, J. (2002). Membandingkan Hasil Analisis Energi Total Menggunakan Bom Kalorimeter dengan Hasil Analisis Proksimat. Temu Teknis Fungsional Non Peneliti (pp. 93-97)

Nayik, G. A., \& Muzaffar, K. (2014). Developments in Packaging of Fresh FruitsShelf Life Perspective: A Review. American Journal of Food Science and Nutrition
Research, 1(5), 34-39. Retrieved from http://www.openscienceonline.com/journal/fs $\mathrm{nr}$

Ndobe, S., Madinawati, Serdiati, N., Syukri, \& Moore, A. (2017). Pertumbuhan Benih Ikan Gabus Channa striata dengan Pakan Cacing Darah Pertumbuhan Benih Ikan Gabus Channa striata dengan Pakan Cacing Darah Beku. Jurnal Sains Teknologi Akuakultur, 1(2), 104 110.

Pertiwi, S. F., Aminah, S., \& Nurhidajah. (2013). Aktivitas Antioksidan, Karakteristik Kimia, dan Sifat Organoleptik Susu Kecambah Kedelai Hitam (Glycine soja) Berdasarkan Variasi Waktu Perkecambahan. Jurnal Pangan Dan Gizi, 04(08), 1-8.

Prastari, C., Yasni, S., \& Nurilmala, M. (2017). Karakteristik Protein Ikan Gabus Yang Berpotensi sebagai antihiperglikemik. JPHPI, 20(2), 413-423. https://doi.org/10.1023/ A:1022252020196

Pulungan, M. H., Sucipto, S., \& Sarsiyani, S. (2016). Shelf Life Prediction of Apple Pia using ASLT Method (Case Study In SMEs (Small and Medium Enterprise) Permata Agro Mandiri Batu Town). Industria: Jurnal Teknologi Dan Manajemen Agroindustri, 5(2), 61-66. https://doi.org/10.21776/ub.industria. 2016.005.02.2

Rahman, M., Molla, M., Sarker, M., Chowdhury, S., \& Shaikh, M. (2018). Snakehead Fish (Channa striata) and Its Biochemical. SF Journal of Biotechnology and Biomedical Engineering, 1(1), 1-5.

Rahman, T., Luthfiyanti, R., \& Ekafitri, R. (2011). Optimasi Proses Pembuatan Food Bar Berbasis Pisang. Prosiding SNaPP2011 Sains, Teknologi, Dan Kesehatan, 2(1), 295-302.

Raisi, A., \& Aroujalian, A. (2010). Effects of Influence Parameters on Color Formation in Glucose Syrups during Storage, (1), 57-61.

Rani, S., Singh, R., Sehrawat, R., Kaur, B. P., \& Upadhyay, A. (2018). Pearl Millet Processing: a Review. Nutrition and Food Science, 48(1), 30-44. https://doi.org/10.1108/NFS-04-20170070

Rao, Q., Rocca-Smith, J. R., \& Labuza, T. P. (2013). Storage Stability of Hen Egg White 
Powders in Three Protein/Water Dough Model Systems. Food Chemistry, 138(2-3), 10871094. https://doi.org/10.1016/j.foodchem.20 12.11 .082

Ratnaningsih, N., Ginting, E., Adie, M. M., \& Harnowo, D. (2017). Sifat Fisiko-Kimia dan Kandungan Serat Pangan Galur-Galur Harapan Kedelai. Jurnal Penelitian Pascapanen Pertanian, 14(1), 35-45. https://doi.org/10.21082/jpasca.v14n1.2017.3 5-45

Regina, M., Affandi, D. R., \& Riyadi, N. H. (2012). Kajian Karakteristik Koya Ikan dengan Behan Dasar Beberapa Macam Ikan dan Tepung Kedelai (Glycine max) sebagai Pelengkap Makanan. Jurnal Teknosains Pangan, 1(1), 28-31.

Romadhoni, A. R., Afrianto, E., Pratama, R. I., \& Grandiosa, R. (2016). Extraction of Snakehead Fish [Ophiocephalus striatus (Bloch, 1793)] Into Fish Protein Concentrate as Albumin Source using Various Solvent. Aquatic Procedia, 7, 4-11. https://doi.org/10.11113/ jt.v78.8138

Sappu, E. E. B., Handayani, D., \& Rahmi, Y. (2014). Pengaruh Substitusi Tepung Terigu dengan Tepung Daun Turi (Sesbania grandiflora) Terhadap Mutu Daging Nabati. Indonesian Journal of Human Nutrition, 1(2), 114-117. https://doi.org/10.21776/ub.ijhn.20 16.003.Suplemen.5

Singh, E. S. (2016). Potential of Millets: Nutrients Composition and Health Benefits. Journal of Scientific and Innovative Research, 5(2), 4650. Retrieved from www.jsirjournal.com

Setyaningsih, D., Ariyantono, A., \& Puspita, M. (2010). Analisis Sensori. IPB Press. Bogor.
Tamanna, N., \& Mahmood, N. (2015). Food Processing and Maillard Reaction Products: Effect on Human Health and Nutrition. International Journal of Food Science, 1-6. https://doi.org/10.1155/2015/526762

Trianto, Y., Sutedja, A. M., \& Trisnawati, C. Y. (2013). Karakteristik Sifat Fungsional Kacang Hijau Kukus dengan Variasi Waktu Pengukusan. Jurnal Teknologi Pangan Dan Gizi, 12(2), 69-74.

Wahyuni, S., Holilah, Asranudin, \& Noviyanti. (2018). Estimation of Shelf Life of Wikau Maombo Brownies Cake Using Accelerated Shelf Life Testing (ASLT) Method with Arrhenius Model. IOP Conference Series: Earth and Environmental Science, 122(1), 07. https://doi.org/10.1088/1755-1315/122/1/ 012082

Wardani, A. K., \& Wardani, I. R. (2014). Eksplorasi Potensi Kedelai Hitam untuk Produksi Minuman Fungsional sebagai Upaya meningkatkan Kesehatan Masyarakat. Jurnal Pangan Dan Agroindustri, 2(4), 58-67.

Yusuf, M., S Wihansah, R. R., Arifin, M., Oktaviana, A. Y., Negara, J. K., Sio, A. K. (2016). Kualitas Fisik, Mikrobiologi dan Organoleptik Sosis Ayam Komersil yang Beredar di Tempat Berbeda di Bogor. Jurnal Ilmu Produksi Dan Teknologi Hasil Peternakan, 04(2), 296-299.

Zoumas, B. L., Amstrong, L. E., Backstrand, Jeffrey R., Chenoweth, W. L., Chinachoti, P., Klein, B. P., Tolvanen, M. (2002). HighEnergy, Nutrient-Dense Emergency Relief Food Product. Washington, D.C.: National Academy Press. 